\title{
Hama Penyakit Utama Tanaman Bawang Merah (Allium Ascalonicum) dan Tindakan Pengendalian di Brebes, Jawa Tengah
}

\author{
Shallot (Allium Ascalonicum) Pests and Its Control Measures in Brebes, Central Java \\ Hermanu Triwidodo $^{1 *}$, Maizul Husna Tanjung ${ }^{1}$ \\ ${ }^{1}$ Departemen Proteksi Tanaman, Fakultas Pertanian, Institut Pertanian Bogor \\ J1. Kamper, Kampus IPB Dramaga, Bogor, Jawa Barat 16680, Indonesia \\ *Email korespondensi: hermanutr@apps.ipb.ac.id
}

Diterima: 7 September 2020 / Disetujui: 30 September 2020

\begin{abstract}
Shallots are one of the important commodities that are consumed by Indonesian people. One problem in the cultivation of shallots is the presence of pests and disease. The aims of this research are to determine the pest disease in shallot and control measures taken by farmers in Brebes, Central Java. This research was conducted in three villages with four onion fields each. Observation of pest attack intensity and disease incidence and intensity is carried out every week for 1 month. Information on how to control pests was obtained through interviews. The results showed that the pests that attacked the onion crop were Spodoptera spp. Onion, while the disease was found to be dead shoots of Phytophthora sp. and purple spots. Alternaria sp. Onion caterpillar pests and shoot death have increased with increasing plant age. Pest control carried out by farmers is the installation of light traps and the application of pesticides.
\end{abstract}

Keywords: Alternaria sp., light trap, Phytophthora sp., pesticides, Spodoptera spp.

\section{ABSTRAK}

Bawang merah merupakan salah satu komoditas penting yang banyak dikonsumsi masyarakat Indonesia. Salah satu kendala dalam budidaya bawang merah yaitu adanya serangan organisme pengganggu tanaman (OPT). Penelitian ini bertujuan mengetahui hama penyakit pada tanaman bawang merah dan tindakan pengendalian yang dilakukan oleh petani di Brebes, Jawa Tengah. Penelitian dilaksanakan pada tiga desa dengan masing-masing empat lahan bawang merah. Pengamatan intensitas serangan hama dan kejadian serta intensitas penyakit dilakukan setiap minggu selama 1 bulan. Informasi mengenai cara pengendalian OPT diperoleh melalui wawancara. Hasil penelitian menunjukkan bahwa hama yang menyerang pertanaman bawang merah yaitu ulat bawang Spodoptera spp., sedangkan penyakit yang ditemukan yaitu mati pucuk Phytophthora sp. dan bercak ungu Alternaria sp.. Serangan hama ulat bawang dan penyakit mati pucuk mengalami peningkatan seiiring dengan bertambahnya umur tanaman. Pengendalian OPT yang dilakukan oleh petani yaitu pemasangan light trap dan aplikasi pestisida.

Kata kunci: Alternaria sp., light trap, Phytophthora sp., pestisida, Spodoptera spp.

\section{PENDAHULUAN}

Bawang merah (Allium ascalonicum) merupakan salah satu komoditas pertanian yang banyak dikonsumsi oleh masyarakat Indonesia sebagai bumbu masakan. Permintaan masyarakat Indonesia terhadap bawang merah dalam kurun waktu tahun 2007 hingga tahun 2010 mengalami peningkatan dari 901102 ton menjadi 1116275 ton (KEMENTAN 2015), yang diikuti oleh peningkatan produksi bawang merah dari 802827 ton menjadi 1046325 ton (BPS 2015). Meskipun begitu, peningkatan produksi bawang merah belum mampu mengimbangi peningkatan permintaan masyarakat.

Salah satu kendala dalam produksi bawang merah yaitu adanya serangan OPT (organisme pengganggu tanaman). Potensi kehilangan hasil oleh OPT pada stadia tanaman tua dan muda dapat mencapai $20-100 \%$ tergantung pengelolaan budidaya bawang merah (Adiyoga et al. 2004).
Hama yang dapat menyerang tanaman bawang merah diantaranya orong-orong Gryllotalpa spp. (Orthoptera: Gryllotalpidae), ulat bawang Spodoptera exigua (Lepidopera: Noctuidae), ulat grayak Spodoptera litura (Lepidoptera: Noctuidae), lalat pengorok daun Liriomyza chinensis (Diptera: Agromyzidae) dan thrips Thrips tabaci (Thysanoptera: Thripidae). Sedangkan penyakit yang dapat menginfeksi tanaman bawang merah diantaranya bercak ungu (Alternaria porri), downy mildew (Peronospora destructor), bercak daun Cercospora (Cercospora duddiae), antraknosa(Colletotrichum gloeosporiodes), layu Fusarium (Fusarium oxysporum) dan nematoda (Dytylenchus dissaci) (Udiarto et al. 2005).

Sebanyak $80 \%$ produksi bawang merah di Indonesia berasal dari Pulau Jawa dan hampir 50\% terkonsentrasi di Jawa Tengah. Kabupaten Brebes merupakan sentra produksi bawang merah di Jawa Tengah (Rachmat et al. 2012). Rata- 
rata produktivitas bawang merah di Kabupaten Brebes mampu mencapai 12.14 ton/ha yang diperoleh dari 12 kecamatan salah satunya Kecamatan Brebes dengan rata-rata produktivitas mencapai 11.69 ton/ha (BPS Kabupaten Brebes 2016). Oleh karena itu, informasi mengenai hama dan penyakit penting pada tanaman bawang merah perlu diketahui untuk menentukan pengendalian yang tepat sasaran.

\section{BAHAN DAN METODE}

Penelitian dilakukan pada Februari hingga April 2016 di Desa Pagejugan, Desa Kedunguter dan Desa Kaliwlingi, Kecamatan Brebes, Jawa Tengah. Identifikasi OPT dilakukan di Laboratorium Klinik Tanaman, Departemen Proteksi Tanaman, Fakultas Pertanian, Institut Pertanian Bogor.

\section{Penentuan Lahan Pengamatan dan Petak Contoh}

Penelitian dilaksanakan dengan melakukan pengamatan langsung pada lahan petani di Desa Pagejugan, Kedunguter dan Kaliwlingi, Kecamatan Brebes, Jawa Tengah. Pengamtan dilakukan pada suhu 25-30 derajat Celsius. Setiap desa ditentukan 4 lahan tanaman bawang merah kemudian dilakukan pengamatan sebanyak empat kali setiap minggu selama satu bulan. Lahan bawang yang diamati yaitu rata-rata seluas 0.5 ha dengan umur tanaman 14 HST. Masing-masing lahan ditentukan 5 bedengan sebagai petak contoh dan pada setiap petak contoh diamati 5 rumpun tanaman contoh. Pengambilan petak contoh dilakukan secara acak. Bedengan di lahan digunakan sebagai petak contoh pada saat pengacakan acak.

\section{Pengamatan Hama}

Setiap tanaman contoh diidentifikasi jenis hama dan dihitung intensitas serangannya. Hama yang tidak dapat diidentifikasi di lapangan diidentifikasi di laboratorium. Intensitas serangan hama dihitung menggunakan rumus (Rivai 2006):

$$
\text { IS }=\sum \frac{(n i . v i)}{N . V} \times 100 \%
$$

Keterangan:

$$
\begin{array}{ll}
I S & =\text { Intensitas serangan hama } \\
n i & =\text { jumlah tanaman terserang dengan skor tertentu } \\
v i & =\text { skor serangan hama } \\
N & =\text { jumlah tanaman diamati } \\
V & =\text { skor serangan hama tertinggi }
\end{array}
$$

Skor serangan hama ( $v i$ ) mengacu pada Febrianasari et al. (2014) yang telah dimodifikasi sebagai berikut:
0 : tidak ada gejala serangan
1: gejala serangan $1-20 \%$
2: gejala serangan $21-40 \%$
3: gejala serangan $41-60 \%$
4: gejala serangan $61-80 \%$
5: gejala serangan $81-100 \%$

\section{Pengamatan Penyakit}

Tanaman contoh yang menunjukkan gejala kemudian diidentifikasi lebih lanjut di laboratorium untuk mengetahui patogen penyebab penyakit tersebut. Kejadian penyakit dihitung berdasarkan rumus:

Keterangan:

$$
K P=\frac{n}{N} x 100 \%
$$

$$
\begin{array}{ll}
K P & =\text { kejadian penyakit } \\
n & =\text { jumlah tanaman terinfeksi } \\
N & =\text { jumlah tanaman diamati }
\end{array}
$$

Keparahan penyakit dihitung berdasarkan rumus Townsend dan Heuberger (1943):

$$
I P=\sum \frac{(n i . v i)}{N . V} \times 100 \%
$$

\section{Keterangan:}

IP = intensitas penyakit

$n i \quad=$ jumlah tanaman terinfeksi dengan skor tertentu

$v i \quad=$ skor infeksi penyakit

$N \quad=$ jumlah tanaman diamati

$V \quad=$ skor infeksi penyakit tertinggi

Skor infeksi penyakt (vi):

0: tidak ada infeksi

1: bagian tanaman terinfeksi $1-20 \%$

2: bagian tanaman terinfeksi $21-40 \%$

3: bagian tanaman terinfeksi $41-60 \%$

4: bagian tanaman terinfeksi $61-80 \%$

5: bagian tanaman terinfeksi $81-100 \%$

Wawancara menggunakan kuisioner juga dilakukan pada 20 petani di masing-masing desa untuk memperoleh informasi mengenai cara pengendalian OPT pada tanaman bawang merah.

\section{Analisis Data}

Data perbedaan intensitas serangan yang disebabkan oleh hama pada setiap desa diolah dengan uji Tukey pada taraf nyata 5\% menggunakan program SAS versi 9.1.3.

\section{HASIL DAN PEMBAHASAN}

\section{Hama Tanaman Bawang Merah}

Ulat bawang Spodoptera exigua merupakan hama yang ditemukan pada seluruh lahan pengamatan bawang merah di masing-masing desa. Hal tersebut sesuai dengan Udiarto et al. (2005) yang menyatakan bahwa S. exigua merupakan salah satu hama pada tanaman bawang. Larva Spodoptera spp. memakan bagian daun. Daun yang terserang $S$. exigua terlihat menerawang dan hanya tersisa epidermis daun epidermis daun (Gambar 1). 


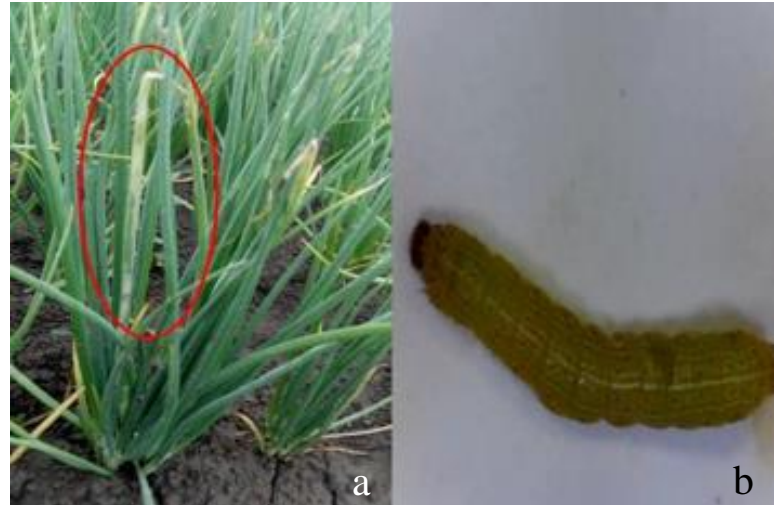

Gambar 1. Hama ulat bawang S. exigua.: (a) gejala, (b) larva

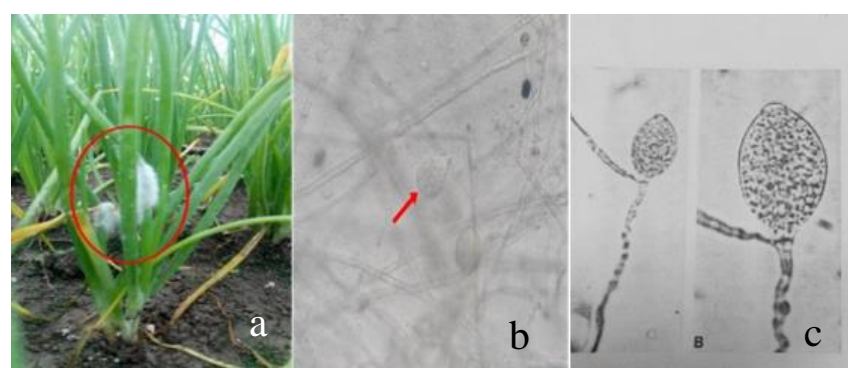

Gambar 2. Penyakit mati pucuk: (a) gejala mati pucuk, (b) mikroskopis cendawan Phytopthora sp. dengan perbesaran 40x10, (c) m ikroskopis cendawan Phytopthora sp. dalam Watanabe (1994).

Hama ulat bawang $S$. exigua menjadi salah satu OPT penting pada bawang merah yang mengakibatkan petani tidak memperoleh hasil produksi maksimal (Febrianasari et al. 2014). Gejala hama ini yaitu timbul bercak-bercak putih transparan pada daun, daun berlubang, terkulai, mengering dan pada serangan berat seluruh daun habis (Moeksan et al. 2013). Intensitas serangan S. exigua terus meningkat seiring dengan bertambahnya umur tanaman bawang merah di ketiga desa (Tabel 1). Peningkatan serangan $S$. exigua berhubungan dengan bertambahnya umur tanaman bawang merah, hal tersebut disebabkan karena semakin banyaknya daun tanaman bawang merah yang terserang (Marsadi et al. 2017). Intensitas serangan $S$. exigua paling tinggi terjadi di Desa Pagejugan pada masing-masing waktu pengamatan, sedangkan Desa Kaliwlingi memiliki intensitas serangan paling rendah. Intensitas serangan di Desa Pagejugan berbeda nyata dengan di Desa Kaliwlingi.

\section{Penyakit Tanaman Bawang Merah}

\section{Phytophthora sp.}

Penyakit yang ditemukan di lahan pengamatan tanaman bawang merah yaitu mati pucuk oleh cendawan Phytophthora sp. (Gambar 2). Penyakit mati pucuk Phytophthora sp. menginfeksi daun dan menimbulkan gejala busuk basah pada pemukaan ujung daun. Masa cendawan dapat berbentuk seperti beludru pada udara lembab. Masa cendawan semakin lama akan menyebar pada permukaan daun, serangan yang berat membuat tanaman mati dengan daun melilit seperti dipilin (Wibowo 2005). Gejala infeksi akibat cendawan Alternaria sp. ditunjukkan berupa adanya bercak berukuran kecil, melekuk ke dalam, berwarna putih dengan pusat yang berwarna ungu (kelabu), bercak akan berkembang menyerupai cincin dengan bagian tengah yang berwarna ungu. Tepi cincin berwarna kemerahan dikelilingi warna kuning yang dapat meluas ke bagian atas maupun bawah bercak. Konidia cendawan ini dapat menyebabkan perubahan warna daun menjadi kuning (Udiarto et al. 2005).

Hasil pengamatan menunjukkan bahwa terjadi peningkatan kejadian dan intensitas penyakit Phytophthora sp. di Desa Pagejugan dari minggu pertama hingga minggu keempat pengamatan. Hal ini menunjukkan bahwa patogen Phytophthora sp. terus mengalami pertumbuhan dan perkembangan seiring dengan bertambahnya umur tanaman bawang merah.

Kejadian penyakit paling tinggi mencapai $83 \%$ dan intensitas penyakit tertinggi mencapai $40.8 \%$ (Gambar 3). Infestasi penyakit ini di Desa Pagejugan diduga berasal dari benih yang ditanam berasal dari tanaman bawang merah sebelumnya yang menggunakan benih bawang merah varietas Bima Brebes. Benih varietas Bima Brebes diketahui merupakan benih yang peka terhadap penyakit mati pucuk Phytophthora sp. (BALITSA 2018). Selain itu, infeksi penyakit mati pucuk muncul diduga karena selama pengamatan berlangsung sedang terjadi musim hujan. Siang hingga malam hari terjadi hujan sehingga suhu menjadi dingin dan kelembapan udara meningkat yang menyebabkan cendawan penyakit mampu tumbuh dan berkembang. Hasil pemodelan epidemi penyakit menunjukkan jika faktor suhu, kelembapan, dan kecepatan angin kuadrat lebih besar maka pengaruhnya terhadap laju infeksi penyakit sangat tinggi (Purwanto et al. 2016).

Tabel 1. Intensitas serangan ulat bawang S. exigua di ketiga desa pada empat waktu pengamatan

\begin{tabular}{lcccc}
\hline \multirow{2}{*}{ Desa } & \multicolumn{4}{c}{ Intensitas Serangan (\%) pada waktu pengamatan (HST) } \\
\cline { 2 - 5 } & $\mathbf{2 1}$ & $\mathbf{2 8}$ & $\mathbf{3 5}$ & $\mathbf{4 9}$ \\
\hline Pagejugan & $17.0 \mathrm{a}$ & $28.1 \mathrm{a}$ & $30.7 \mathrm{a}$ & $37.0 \mathrm{a}$ \\
Kedunguter & $2.0 \mathrm{ab}$ & $16.8 \mathrm{a}$ & $21.1 \mathrm{ab}$ & $35.4 \mathrm{a}$ \\
Kaliwlingi & $0.0 \mathrm{~b}$ & $0.0 \mathrm{~b}$ & $2.5 \mathrm{~b}$ & $3.1 \mathrm{~b}$ \\
\hline
\end{tabular}

Keterangan : HST $=$ Hari Setelah Tanam. Angka yang diikuti huruf sama pada kolom yang sama menunjukkan tidak berbeda nyata berdasarkan uji Tukey $(\alpha=0.05)$ 


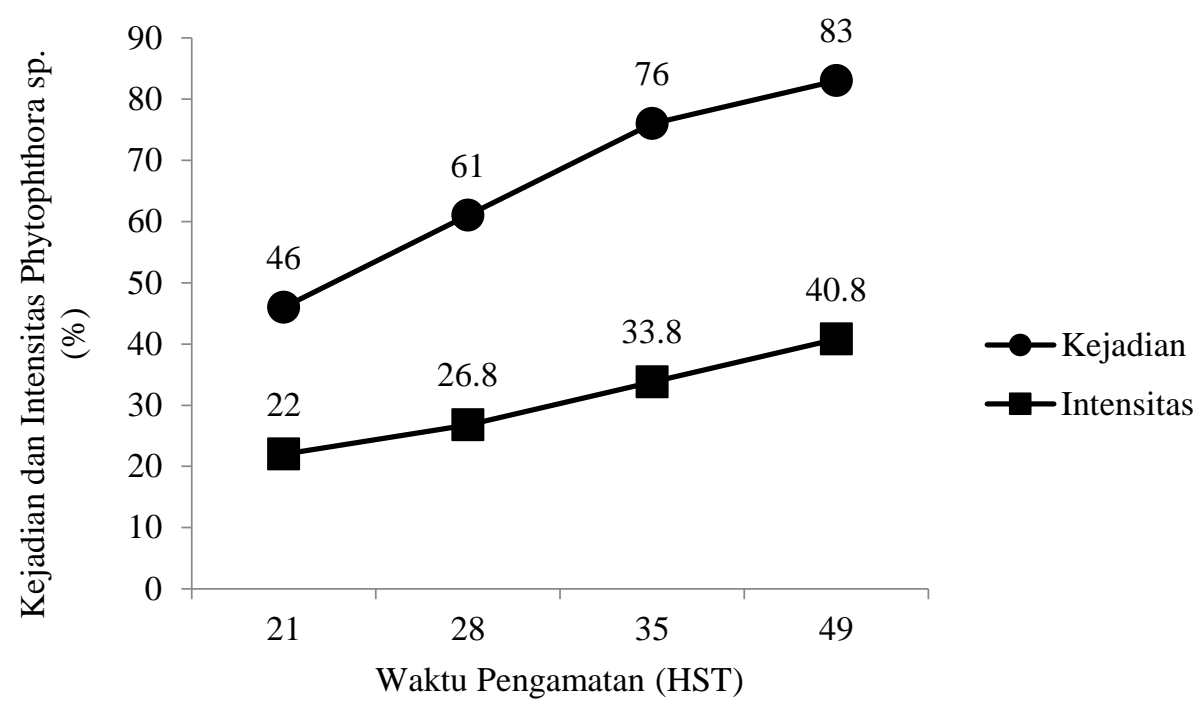

Gambar 3. Kejadian dan intensitas penyakit Phytophthora sp. pada empat waktu pengamatan di Desa Pagejugan

\section{Alternaria sp.}

Hasil pengamatan mikroskopis ditemukan cendawan Alternaria sp. dengan kondia yang mempunyai sekat melintang dan membujur (Gambar 4), hanya saja gejala infeksi awal pada daun belum terlihat di lahan pengamatan. Gejala infeksi akibat cendawan Alternaria sp. ditunjukkan berupa adanya bercak berukuran kecil, melekuk ke dalam, berwarna putih dengan pusat yang berwarna ungu (kelabu), bercak akan berkembang menyerupai cincin dengan bagian tengah yang berwarna ungu.Tepi cincin berwarna kemerahan dikelilingi warna kuning yang dapat meluas ke bagian atas maupun bawah bercak (Udiarto et al. 2005). Penyakit bercak ungu ini dapat menurunkan hasil sebanyak 50\% di Lembang, Jawa Barat (Gunaeni 2015).

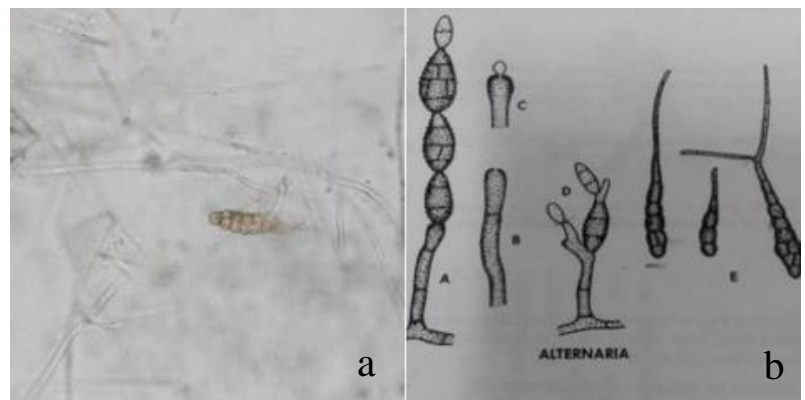

Gambar 4. Konidia cendawan Alternaria sp.: (a) bentuk mikroskopis pada perbesaran 40x10,(b) bentuk mikroskopis dalam Barnett dan Hunter 1998.

\section{Tindakan Pengendalian OPT}

Pengendalian OPT yang dilakukan oleh semua petani di ketiga desa yaitu menggunakan pestisida (Tabel 2). Alasan petani menggunakan pestisida dalam pengendalian OPT diantaranya karena efektif, mudah didapatkan, praktis dalam aplikasi, harga murah dan mendapatkan saran dari orang lain. Pengendalian OPT menggunakan pestisida dinilai praktis oleh petani karena hanya menyemprot menggunakan hand sprayer.

Petani juga melakukan pencampuran pestisida karena pertanaman bawang merah diserang berbagai jenis OPT secara bersamaan. Menurut petani, semakin banyak jenis pestisida yang digunakan maka akan semakin efektif dalam pengendalian OPT. Frekuensi penggunaan pestisida lebih intensif pada saat musim hujan dibandingkan musim kemarau. Hal ini karena petani beranggapan bahwa pestisida yang telah diaplikasikan pada tanaman tercuci oleh air hujan sehingga aplikasi harus dilakukan lebih intensif agar tetap efektif dalam mengendalikan OPT.

Berdasarkan hasil wawancara, terdapat 16 bahan aktif insektisida dan 9 bahan aktif fungisida yang digunakan oleh petani bawang merah di ketiga desa. Bahan aktif insektisida yang sering digunakan petani bawang merah di ketiga desa yaitu klorfenapir, emamektin benzoat, abamektin, klorpirifos dan siromazin. Bahan aktif fungisida yang paling banyak digunakan adalah mankozeb, klorotalonil dan propineb.

Tindakan pengendalian OPT yang dilakukan petani tidak hanya mengandalkan penggunaan pestisida. Alternatif cara pengendalian Petani Desa Kaliwlingi memilih menggunakan light trap sebagai alternatif tindakan pengendalan OPT. Hal tersebut menyebabkan Desa Kaliwlingi memiliki intensitas serangan hama S. exigua di Desa Kaliwlingi paling rendah. Hal ini menunjukkan bahwa penggunaan light trap dapat mengurangi serangan ulat $S$. exigua pada tanaman bawang. Hasil Penelitian Sari et. al (2017) penggunaan light trap efektif dalam memerangkap ngengat $S$. exigua dengan jumlah tangkapan terbanyak menggunakan light trap dengan warna lampu putih.

Petani Desa Kaliwlingi memilih menggunakan light trap sebagai alternatif tindakan pengendalian karena harga pestisida untuk pengendalian ulat bawang tidak terjangkau oleh petani. Penggunaan light trap menurut petani mampu mengurangi pengeluaran insektisida untuk ulat bawang sebesar 50\% dari pengeluaran tanpa menggunakan light trap. 
Tabel 2. Tindakan pengendalian OPT dan alasan penggunaan pestisida pada tanaman bawang merah

\begin{tabular}{lccc}
\hline \multirow{2}{*}{ Indikator } & \multicolumn{2}{c}{ Petani $(\%)$} \\
\cline { 2 - 4 } & Pagejugan & Kedunguter & Kaliwlingi \\
\hline Tindakan dalam pengendalian OPT & 100 & 100 & 100 \\
$\quad$ Pestisida & 0 & 0 & 0 \\
Tindakan lain & & 35 & 50 \\
Alasan penggunaan pestisida & 65 & 15 & 35 \\
Efektif & 25 & 85 & 80 \\
Mudah didapatkan & 75 & 0 & 30 \\
Praktis dalam aplikasi & 20 & 15 & 15 \\
Harga murah & 15 & & \\
Saran dari orang lain & & & \\
\end{tabular}

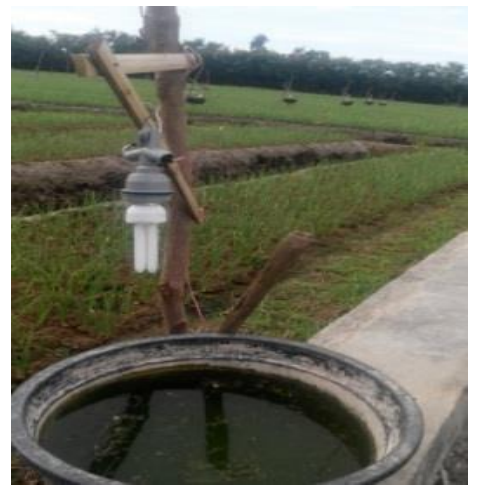

Gambar 5. Pengendalian hama ulat bawang menggunakan light trap

Light trap dibuat langsung oleh petani dengan penggunaan lampu listrik, digantungkan tegak pada tiang bambu dengan ketinggian kurang lebih $50 \mathrm{~cm}$ sebagai penyangga. Light trap dipasang dengan jarak 5-10 m di antara bedengan tanaman, di bawah lampu terdapat wadah plastik bertujuan untuk menampung hama yang terperangkap (Gambar 5). Light trap dinyalakan selama kurang lebih 12 jam yaitu mulai pukul 18.00 sampai pukul 06.00 WIB. Serangga tertarik karena ada cahaya lampu dan akan jatuh ke dalam wadah yang sudah berisi insektisida, serangga yang terperangkap dalam wadah plastik akan mati. Petani tetap menggunakan insektisida dalam pengendalian walaupun sudah menggunakan perangkap.

\section{KESIMPULAN}

Hama yang ditemukan pada pertanaman bawang merah di Kecamatan Brebes yaitu ulat bawang Spodoptera spp., sedangkan untuk penyakit yang ditemukan yaitu mati pucuk Phytophthora sp. dan bercak ungu Alternaria sp.. Pengendalian OPT yang dilakukan oleh petani yaitu pemasangan light trap dan aplikasi pestisida.

\section{DAFTAR PUSTAKA}

Adiyoga, W., Laksanawati, A., Soetiarso, T.A., \& Hidayat, A. (2001). Persepsi petani terhadap status dan prospek penggunaan SeMNPV pada usahatani bawang merah. J Hort.11(1), 58-70.
BALITSA. (2018). Bawang merah varietas bima brebes. http://balitsa.litbang.pertanian.go.id/ind/index.php/v arietas/cabai/36-halaman/616-bawang-merahvarietas-bima-brebes

Barnett, H.L., \& Hunter, B.B. (1998). Illusturad genera of imperfect fungi. $4^{\text {th }}$ ed. Minnesota, US: APS Press.

[BPS] Badan Pusat Statistik. (2015). Produktivitas bawang merah 2006-2011. [Internet]. [diunduh 2015 Mei 29]. Tersedia pada: http://www.bps.go.id/site/resultTab.

[BPS Kabupaten Brebes] Badan Pusat Statistika Kabupaten Brebes. (2016). Luas panen, produksi dan rata-rata produksi bawang merah di Kabupaten Brebes 20122014. [Internet]. [Diunduh 2016 Agst 05]. Tersedia pada:

https://brebeskab.bps.go.id/linkTableDinamis/view/i $\underline{\mathrm{d} / 21}$.

Febrianasari, R., Tarno, H., \& Afandhi, A. (2014). Efektivitas klorantraniliprol dan flubendiamid pada ulat bawang merah (Spodoptera exigua Hubner.) (Lepidoptera:Noctuidae). J PHT, 2(4), 103-109.

Gunaeni, N. (2015). Pengendalian hama dan penyakit secara fisik dan mekanik pada produksi bawang daun (Allium fistolosum L.). Jurnal Agrin, 19 (1), 37-51.

[KEMENTAN] Kementerian Pertanian. (2015). Konsumsi per kapita dalam rumah tangga setahun menurut hasil Susenas. [Internet]. [Diunduh 2016 Sept 05]. Tersedia pada: https://aplikasi2.pertanian.go.id/ konsumsi/tampil_susenas_kom2_th.php.

Marsadi, D., Supartha, I.W., \& Sunari, S.A.A.A.A. (2017). Invasi dan tingkat serangan ulat bawang (spodoptera exigua hubner) pada dua kultivar tanaman bawang merah di desa songan, kecamatan kintamani, kabupaten bangli. Jurnal Agroekoteknologi Tropika, 6(4), 360-369.

Moeksan, T.K., Setiawati, W., Hasan, F., Runa. R., \& Soemantri, A. (2013). Penerapan ambang 
pengendalian Spodotera exigua pada tanaman bawang merah menggunakan feromonoid seks. $J$ Hort, 23(1), 80-90.

Moeksan, T.K., \& Basuki, R.S. (2007). Status resistensi Spodoptera exigua Hubn. pada tanaman bawang merah asal Kabupaten Cirebon, Brebes, dan Tegal terhadap insektisida yang umum digunakan petani di daerah tersebut. J Hort, 17(4), 343-354.

Purwanto, D. S., Nirwanto, H., \& Wiyatiningsih, S. (2017). Model epidemi penyakit tanaman: hubungan faktor lingkungan terhadap laju infeksi dan pola sebaran penyakit bulai (Peronosclerospora maydis). Plumula. 5(2), 138-152.

Rachmat, M., Sayaka, B., \& Muslim, C. (2012). Produksi, perdagangan, dan harga bawang merah. [Internet]. [Diunduh 2016 Agst 23]. Tersedia pada: http://pse.litbang.pertanian.go.id/ind/pdffiles/anjak_ 2012_09.pdf.

Rivai, F. (2006). Kehilangan Hasil Akibat Penyakit Tanaman. Padang, ID: Andalas Universiti Press.
Sari, Y.M., Prastowo, S., \& Haryadi, N.T. (2017). Uji ketertarikan ngengat Spodoptera exigua hubn. Terhadap perangkap lampu warna pada pertanaman bawang merah (Allium ascalonicum L.). Agrovigor, $10(1), 1-6$.

Townsend, G.R., \& Heuberger, J.V. (1943). Methods for estimating losses caused by diseases in fungicide expreminent. Plant Disease Report, 27(17), 340-343.

Udiarto, B., Setiawati, W., \& Suryaningsih, E. (2005). Pengenalan hama dan penyakit pada tanaman bawang merah dan pengendaliannya. Panduan teknis ptt bawang merah no.2. Bandung, ID: Balai Penelitian Tanaman Sayuran (BALITSA).

Watanabe, T. (1994). Pictorial atlas of soil and fungi morphologies of cultured fungi and key to species. $2^{\text {nd }}$ ed. Boca Raton, USA: CRC Press.

Wibowo, S. (2005). Budidaya bawang merah. Jakarta, ID: Penebar Swadaya. 